\title{
GAMBARAN HEMATOLOGI PADA PASIEN SINDROM KORONER AKUT YANG DIRAWAT DI BLU RSUP PROF. Dr. R.D. KANDOU MANADO TAHUN 2010
}

\author{
${ }^{1}$ Bagus Yuvi Setyo Ramadhani \\ ${ }^{2}$ L. W. A. Rotty \\ ${ }^{2}$ Frans Wantania
}

\author{
${ }^{1}$ Kandidat Skripsi Fakultas Kedokteran Universitas Sam Ratulangi Manado \\ ${ }^{2}$ Bagian Ilmu Penyakit Dalam Fakultas Kedokteran Universitas Sam Ratulangi Manado \\ Email:paai_manado@yahoo.com
}

\begin{abstract}
Acute coronary syndrome (ACS) is a series of clinical disorders caused by acute ischemic heart disease, including angina unstable, non-ST elevation myocardial infarction, and ST-elevation myocardial infarction. This study aimed to determine the relationship of routine hematological changes with the course of acute coronary syndromes. We used a descriptive method. Data were obtained from the secondary data of ACS patients in the ICCU RSUP Prof. Dr. R. D. Kandou Manado during 2010. The data were presented in distributive tables. The results showed that most patients did not experience decreases in hematological parameters such as hemoglobin, hematocrite, erythrocyte counts, and platelet counts. The leucocyte counts increased in 50\% of cases. Conclusion: In general, there was no decrease in hematological parameters, except leukocyte counts, among the ACS patients in the ICCU RSUP Prof. Dr. R. D. Kandou Manado during 2010.
\end{abstract}

Keywords: acute coronary syndrome, coronary heart disease, hematology, inflammation

\begin{abstract}
Abstrak: Sindrom koroner akut (SKA) merupakan rangkaian gangguan klinis yang disebabkan oleh penyakit akut iskemik jantung, termasuk angina tidak stabil, non-ST elevasi miocard infraction, dan ST-elevasi miocard infraction. Penelitian ini bertujuan untuk mengetahui hubungan perubahan hematologi rutin dengan perjalanan penyakit sindrom koroner akut. Penelitian ini memakai metode deskriptif dengan menggunakan data sekunder dari penderita SKA di ruang ICCU RSUP Prof. Dr. R. D. Kandou Manado selama tahun 2010. Data hasil penelitian disajikan dalam bentuk tabel distributif. Hasil penelitian memperlihatkan bahwa sebagian besar pasien tidak memperlihatkan penurunan parameter hematologi. Jumlah leukosit meningkat pada 50\% kasus. Simpulan: Umumnya tidak terdapat penurunan parameter hematologi, kecuali jumlah leukosit pada pasien SKA ruang ICCU RSUP Prof. Dr. R. D. Kandou Manado selama tahun 2010.
\end{abstract}

Kata kunci: Sindrom koroner akut, penjakit jantung koroner, Hematologi, inflamasi

Sindrom koroner akut ini merupakan sekumpulan manifestasi atau gejala akibat penyakit arteri koroner, adapun patofisiologi gejala-gejala tersebut adalah sama (berurut peristiwa patologisnya) ditandai oleh erosi, fisuri, atau pecahnya plak yang memang sudah ada, selanjutnya mengarah ke trombosis (penggumpalan) dalam arteri koroner dan menyebabkan kondisi bagi ancaman kehidupan pasien dengan penyakit arteri yang menganggu suplai darah ke otot jantung. ${ }^{1}$

Sindrom koroner akut mencakup penyakit jantung koroner (PJK), termasuk didalamnya angina tidak stabil, infark miokard ST-elevasi (STEMI), dan non- 
STEMI (NSTEMI). Ketiga gangguan ini disebut sindrom koroner akut karena gejala awal serta manajemen awal sering serupa. ${ }^{2}$

Penyakit jantung koroner adalah penyebab utama kematian di seluruh dunia, dan 3,8 juta pria serta 3,4 juta perempuan meninggal akibat penyakit tersebut setiap tahun. Penyakit jantung koroner merupakan penyebab 48\% kematian akibat penyakit kardiovaskular pada tahun 1998 di Amerika Serikat. ${ }^{3,4}$

Pemeriksaan hematologi (darah) lengkap adalah tes hematologi khusus yang digunakan untuk membantu menegakkan diagnosis, menunjang diagnosis, membantu diagnosis banding, memantau perjalanan penyakit, menilai beratnya sakit, menentukan prognosis. ${ }^{5}$

Penelitian ini bertujuan untuk mengetahui peranan inflamasi dengan perjalanan penyakit sindrom koroner akut. Yang dimana tanda-tanda inflamasi ini dapat dilihat dari data atau gambaran hematologi rutin seseorang.

\section{METODE PENELITIAN}

Penelitian yang dilakukan bersifat deskriptif dengan menggunakan data sekunder sebagai acuan. Penelitian ini memakai metode deskriptif dengan menggunakan data sekunder dari penderita Sindrom koroner akut di ruang ICCU RSUP Prof. Dr. R. D. Kandou Manado selama tahun 2010.

Data penelitian diambil mulai bulan Januari 2010-Desember 2010. Tempat pelaksanaan penelitian adalah ruang ICCU BLU RSUP Prof. dr. R.D. Kandou Manado. Populasi penelitian adalah pasien yang berkunjung di ruang ICCU BLU RSUP Prof. dr. R. D. Kandou Manado. Sampel penelitian ini adalah penderita Penyakit Sindrom Koroner Akut yang dirawat di ruang ICCU BLU RSUP Prof. dr. R.D. Kandou Manado selama tahun 2010.

Adapun kriteria inklusi yang digunakan antara lain: pasien yang berkunjung akibat sindrom koroner akut, dan pasien sindrom koroner akut dengan data pemeriksaan hematologi.

Kriteria eksklusi yang digunakan an- tara lain: pasien sindrom koroner akut dengan stroke, pasien koroner akut menolak perawatan di ruang ICCU, pasien sindrom koroner akut memiliki kelainan hematologi, dan pasien koroner akut memiliki riwayat penyakit gagal ginjal.

Penelitian ini juga dilakukan menggunakan beberapa variabel penelitian yaitu: usia, jenis kelamin, dan pekerjaan. Juga gambaran hematologi berupa, eritrosit, leukosit dan trombosit pasien sindrom koroner akut

Cara kerja pelaksanaan penelitian ini adalah dengan mengumpulkan data kasus pasien yang telah didiagnosis dengan Penyakit Sindrom Koroner Akut beserta gambaran hematologinya selama tahun 2010. Kemudian data dikelompokan berdasarkan variabel penelitian dan disajikan dalam bentuk tabel. Penelitian ini akan diolah secara deskriptif dan disajikan dalam bentuk tabel dan presentase

\section{HASIL DAN BAHASAN}

\section{Distribusi sampel berdasarkan usia}

Gambar 1. Distibusi Sampel berdasarkan usia.

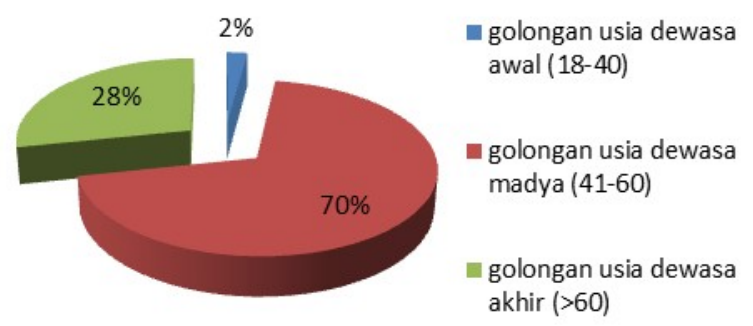

Hal ini menjelaskan bahwa tingkat kejadian sindrom koroner akut meningkat dengan peningkatan usia. Dimana menurut teori peningkatan angka kejadian sindrom koroner akut saat menopause pada wanita lebih besar dibanding dengan wanita dewasa awal. Perubahan usia adalah salah satu prognosticators terkuat untuk penyakit sindrom koroner akut (SKA) tetapi dapat dikacaukan oleh kehadiran faktor lainnya dan kondisi komorbid. ${ }^{6}$ 


\section{Distribusi sampel berdasarkan jenis ke- lamin}

Distribusi angka kejadian sindrom koroner akut berdasarkan jenis kelamin dapat dilihat pada gambar 2 berikut.

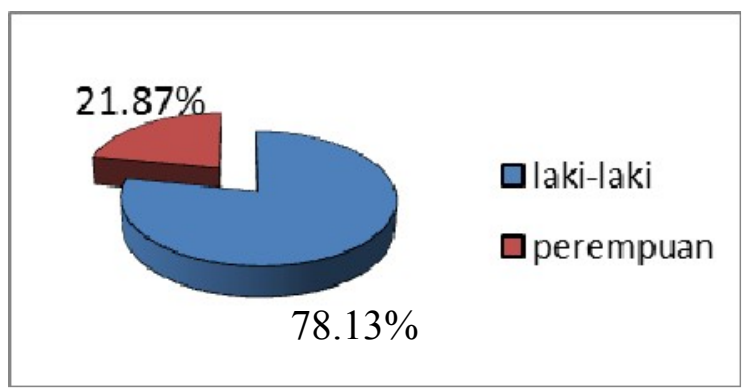

Gambar 2. Distibusi Sampel berdasarkan jenis kelamin.

Hal ini menyatakan jumlah pasien laki-laki (50 pasien) lebih banyak dari pada perempuan (14 pasien) pada kasus sindrom koroner akut. Rasio antara laki-laki: perempuan adalah 7:3. Berdasarkan teori yang ada hal ini dikarena laki-laki lebih rentan akibat faktor-faktor resiko yang ada antara lain merokok, kholesteror (faktor makanan), dan lain-lainnya. ${ }^{6}$

\section{Distribusi nilai hemoglobin}

Distribusi perbandingan nilai hemoglobin dari 56 pasien, di antaranya 18 pasien dengan penurunan nilai hemoglobin dan 38 pasien dengan nilai hemoglobin yang masih dalam keadaan normal. Bisa terlihat jelas dalam Gambar 3 berikut.

Hal ini menunjukkan bahwa teori yang menjelaskan tentang adanya pengaruh anemia terhadap beban jantung belum begitu terlihat pada kasus sindrom koroner akut. Seperti pada teori yang dijelaskan di atas maka diketahui bahwa pada sindrom koroner akut yang merupakan penyakit akut belum terdapat gejala-gejala anemia seperti pada penyakit jantung lainnya terkhusus penyakit jantung yang bersifat kronis. $^{5}$

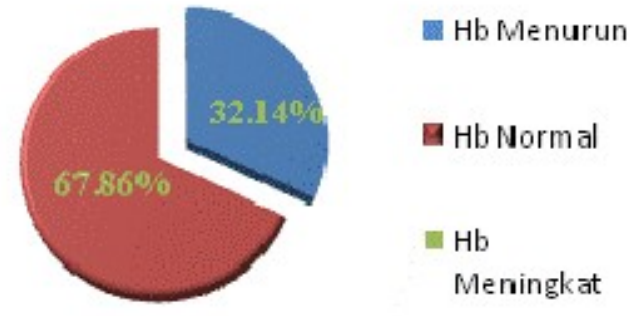

Gambar 3. Distibusi perbandingan nilai hemoglobin.

\section{Distribusi nilai hematokrit}

Berdasarkan hasil penilitian hematokrit pada pasien sindrom koroner akut di dapati data seperti di Gambar 4 berikut.

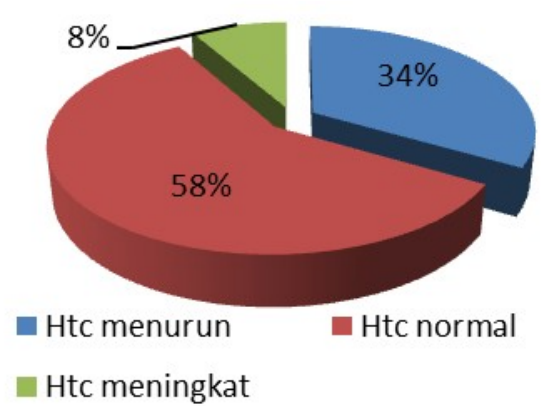

Gambar 4. Distibusi perbandingan nilai hematokrit.

\section{Distribusi perbandingan nilai RBC}

Berdasarkan data yang didapat pada pasien dengan pemeriksaan nilai $\mathrm{RBC}$, 11pasien (57.89\%) memiliki nilai RBC normal, sedangkan delapan pasien (42.11\%) lainnya terjadi penurunan nilai RBC. Bisa terlihat jelas perbandingannya pada Gambar 5.

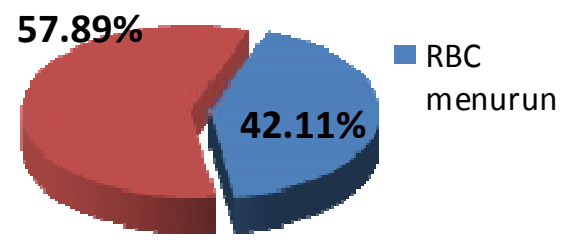

Gambar 5. Distibusi perbandingan nilai red blood cell. 


\section{Distribusi perbandingan nilai WBC}

Berdasarkan hasil penelitian yang didapat makan perbandingan nilai WBC dapat dilihat di Gambar 6 berikut.

\section{Distribusi pebandingan nilai trombosit}

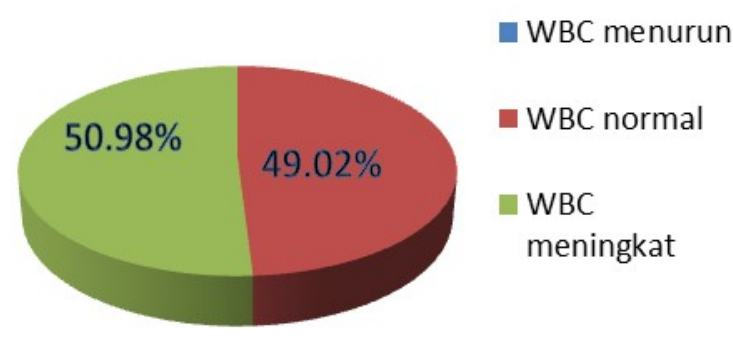

Gambar 6. Distibusi perbandingan nilai white blood cell.

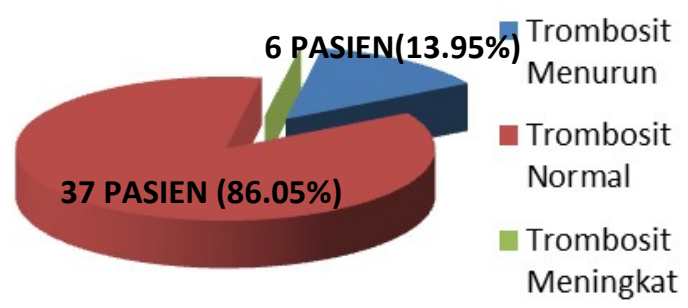

Gambar 7. Distibusi perbandingan nilai trombosit.

Adanya penurunan nilai trombosit (trombositopenia) dapat dikategorikan oleh tiga kategori penyebab utama yaitu: gangguan produksi, peningkatan penghancuran atau konsumsi, dan karantina limpa.

Beberapa data hasil penelitian ini yang terdiri dari :

1. Pasien sindrom koroner akut di tahun 2010 paling banyak pada kelompok usia 41-60 tahun (usia dewasa akhir).

2. Jumlah pasien laki-laki (50 pasien) lebih banyak dari pada perempuan (14 pasien) pada kasus sindrom koroner akut tahun 2010.

3. Pada pemeriksaan hemoglobin pasien dengan nilai hemoglobin normal $67.85 \%$ (38 pasien) jauh lebih banyak dari pada pasien dengan penurunan hemoglobin yaitu $32.14 \%$ (18 pasien) maupun peningkatan hemoglobin yang tidak satu ada.

4. Pada pemeriksaan hematokrit pasien dengan nilai hematokrit normal adalah $58.33 \%$ (tujuh pasien) jauh lebih banyak dari pada pasien dengan penurunan hematokrit 33.33\% (empat pasien) serta pasien dengan peningkatan hematokrit $8.33 \%$ (satu pasien).

5. Pada pemeriksaan eritrosit atau Red Blood Cell (RBC) pasien dengan nilai normal RBC berjumlah $57.89 \%$ (sebelas pasien) sedangkan pasien dengan penurunan RBC berjumlah $42.10 \%$ (delapan pasien).

6. Pada pemeriksaan leukosit atau White Blood Cells total terdapat kesamaan jumlah pada pasien dengan nilai WBC total maupun pasien dengan nilai WBC total yang meningkat adalah sebanyak $50 \%$ atau massing-masing berjumlah 25 pasien.

7. Pada pemeriksaan trombosit atau jumlah platelet terdapat perbedaan yang begitu berarti antara pasien dengan nilai trombosit noraml yakni $86.04 \% \quad$ (37 pasien) dan pasien dengan nilai trombosit yang menurun $13.95 \%$ (enam pasien)

Hal-hal tersebut di atas tadi mempertegas bahwa inflamasi adalah salah satu faktor pencetus penyebab sindrom koroner akut. Namun karna ada beberapa keterbatasan yang ada membuat pemahaman ini sulit untuk di tanggapi, beberapa keterbatasan dalam penelitian yakni sebagai berikut:

\section{Keterbatasan waktu}

Masih banyak faktor-faktor yang berhubungan dengan kecukupan energi dan dapat dijadikan variabel bebas dalam penelitian ini. Namun karena kemampuan penulis terbatas dalam hal waktu dan tenaga maka variabel bebas yang digunakan terbatas. 


\section{Keterbatasan data penelitian}

Masih banyak faktor-faktor yang berhubungan dengan ketepatan penelitian baik yang disengaja dan tidak disengaja dalam penelitian ini. Namun karena kemampuan penulis terbatas dalam data sekunder sehingga data yang digunakan terbatar.

\section{SIMPULAN DAN SARAN}

Sebagai simpulan yang dapat ditarik dari penelitian ini adalah:

1. Pasien sindrom koroner akut paling banyak pada kelompok usia 41-60 tahun.

2. Dengan bertambahnya usia, risiko kejadian kasus sindrom koroner akut mutlak meningkat secara signifikan sebagai akibat dari progresif akumulasi aterosklerosis koroner.

3. Jumlah pasien laki-laki lebih banyak daripada perempuan pada kasus Sindrom Koroner Akut.

4. Rasio kejadian sindrom koroner akut antara laki-laki: perempuan adalah $7: 3$ berdasarkan teori yang ada dikarena laki-laki lebih rentan akibat faktor-faktor resiko yang ada antara lain merokok, kolesterol (faktor makanan), dan lainlainnya.

5. Beberapa data hasil penelitian ini mempertegas bahwa inflamasi adalah salah satu faktor pencetus penyebab sindrom koroner akut. Yang dimana tanda-tanda inflamasi ini dapat dilihat dari data atau gambaran hematologi adalah:

Adapun saran yang dapat diberikan

1. Perlunya perapihan pada penulisan data rekam medis pasien.

2. Perlunya anamnesis lengkap pada pasien maupun keluarga pasien.

3. Perlunya edukasi pada pasien.

4. Perlunya pengawasan dan pengkontrolan khusus pada pasien

\section{DAFTAR PUSTAKA}

1. M Shiel WC, Stoppler C. In: Webster's New World ${ }^{\mathrm{TM}}$ Medical Dictionary (3rd Ed). Wiley Publishing: New Jersey, 2008.

2. Achar S, Kundu S, Norcross W. Diagnosis of acute coronary syndrome. J Am Acad Fam Physician. 2005.

3. Burns D, Kumar V. Jantung. Dalam: Kumar V, Cotran R, Robbins S (ed). Buku Ajar Patologi vol. 2 (Edisi Ketujuh). Jakarta: EGC, 2007.

4. Brown C. Penyakit aterosklerosis. Dalam: Price S, Wilson L, editor. Buku Ajar Patofisiologi. Jakarta: EGC, 2005.

5. Wallach J. Introduction to normal values. In: Interpretation of diagnostic tests. New york: Lippincott Williams \& Wilkins, 2006.

6. Witt BJ, and Roger VL. Population-based sex differences in disease incidence and prevalence. In: Coronary disease in women. New Jersey: Humana Press, 2008.

7. Nabili S, Stoppler M. Thrombocytopenia (Low Platelet Count) [homepage on the Internet]. 2012 